\title{
Cultural Tourism in Bangladesh, a Potential and Profound Tourism Destination: Developing a Model for Cultural Tourism Development in Bangladesh
}

\author{
Mohammad Abu Horaira ${ }^{1 *}$ \\ Aparna Devi ${ }^{2}$ \\ College of Tourism and Hospitality Management (CTHM) \\ International University of Business Agriculture and Technology (IUBAT), Bangladesh
}

\begin{abstract}
Bangladesh is a significant source of many fascinating cultural diversions that can make a fancy trip to many domestic and international tourists. This paper has tried to focus on the cultural tourism of Bangladesh by allocating the facts of historic and traditional culture, cultural tourists' attraction, prospects, development strategy etc. Moreover, the major concern of the authors is to provide a detailed discussion about the main cultural attributes for the tourist or cultural tourists of Bangladesh. Tourism research methods and cultural consumption are some of the most important aspects of cultural tourism in Bangladesh. The researchers also tried to find out the potential of Bangladeshi culture, the scenario of cultural tourism, cross-cultural connection etc. This research paper is the full exploration of only about cultural tourism sector of Bangladesh. All the related information has been collected from available secondary data sources and the writer of this paper attempts to review all the roles of cultural tourism in Bangladesh.
\end{abstract}

Keywords: Culture, Tourism, Development, Tourists, Bangladesh

Corresponding author: Mohammad Abu Horaira; E-mail: horaira@iubat.edu DOI: https://doi.org/10.37227/ITHJ-2021-08-1187/

\section{Introduction}

Tourism has been tested with continuous growth and concentrating diversification over the decades to become one of the fastest-growing economic sectors within the world. Current tourism trends are closely related to further development and encompass a growing number of latest and alternative destinations. These growing demands have changed tourism into a key driver for socio-economic advancement. Cultural tourism is one of the oldest forms of travel and still continues to be a cornerstone of the tourism industry in most parts of the world. The broad concept of culture has led to a growing supply of cultural goods and services, along with a rise in cultural practice (Escudero, 2018). According to the World Tourism Barometer (2019), Statistical Annex, January 2020 and OECD Tourism Statistics (Database) the provisional data indicates that destinations worldwide registered around 1.5 billion international tourist arrivals in 2019, an increase of 3.8\% year-on-year (OECD, 
2020). Cultural locations, attractions, events and competitions provide a crucial motivation for travel, and travel in itself generates culture (Richards, 2018). Cultural tourism is a meeting with diverse cultures in the world which help to know different people and their ways of lifestyle, customs, traditions, and cultural heritage. Tourists travel to different destinations for various reasons and purposes such like they travel for vacation, recreation, business travel, migration and more especially want to experience a new lifestyle, different traditions and explore cultural diversities (Dong, 2020). Cultural tourism also has the goal of studying knowledge from the way of people lives, customs and traditions of people in various countries. (Khawnnapa, 2021).

As a matter of fact, in recent decades, the link between culture and tourism has been more apparently defined as a specific form of expenditure. The evolution of cultural tourism as a social phenomenon and as a purpose of academic study can be traced back to the rise of leisure travel in post-World War II. The growing concept of cultural tourism has been influencing a variety of emerging niches, like heritage tourism, arts tourism, gastronomic tourism, film tourism and creative tourism. The changing nature of cultural tourism was recently brought into focus by a UNWTO Report on Tourism and Culture Synergies (2018), including online surveys covering 43\% of UNWTO Member States in addition to 61 international experts and academics within the field. This study confirmed the importance of cultural tourism, with $89 \%$ of national tourism administrations indicating that cultural tourism is part of their tourism policy. Recently UNWTO at the 22nd Session of the General Assembly held in Chengdu, China (UNWTO, 2017: 18): redefined, cultural tourism as of tourism activity in which the visitor's essential motivation is to find out, discover, experience and consume the tangible and intangible cultural products during a tourism destination. These cultural products related to a collection of distinctive material, intellectual, spiritual and emotional features of a society that encompasses arts and architecture, historical and cultural heritage, culinary heritage, literature, music, dance, dressings, creative artistries and thus the living cultures with their lifestyles, religion, value systems, beliefs and traditions. This redefined definition highlighted the much broader concept of contemporary cultural tourism, which relates not just to sites and monuments, but to human lifestyles and their everyday culture.

Even the growing demand for destinations to differentiate themselves from one another stimulating variety of initiatives and projects those attempt to especially promote the potentials of cultural tourism and creative industries to ultimately also encourage local tourism (Leuschen et al., 2020). There are different wings associated with cultural tourism that relate to space and time, including the attractiveness of a region for cultural tourism, suitable infrastructure, the preparedness of a region (Št'astná et al., 2020). Furthermore, there is also its community to use the presuppositions and role of public administration, information, marketing and advertising, the economy of cultural tourism (public/private partnership), the relation of cultural tourism to other branches, and limiting tourist occlusion of the region (Št'astná et al., 2020).

\section{Objectives of the Study}

The purpose of this paper is especially to explore the cultural tourism of Bangladesh and evaluate and determine further development products provided by cultural tourism attractions. By studying the paper tourists, tourism service providers, related government authorities and other tourism stakeholders can get thoughts and concepts to satisfy tourists' cultural needs and also the necessity of preserving cultural products and attractions. 


\section{Rational of the study}

The research outcome will be helpful for the cultural tourists, tourists, local community, tourism and hospitality service providers, travel and tourism developers, academics of the area, researchers, government, investors and other interested stakeholders. This research may also provide information for the overall cultural tourism branding of Bangladesh.

\section{Literature Review}

Cultural Tourism is one of the largest commercial and entertainment sectors for a country or region. It is the pool of traditional \& cultural activities which creates much interest to domestic and foreign tourists especially to the cultural tourists. Boit et al., (1970) separated several attributes into three dimensions related to cultural destinations. Three dimensions that they use are destination environment (price level in the area, weather, accessibility, wilderness, remoteness, personal safety, transportation, culture), atmosphere (quality of service, lack of language barrier, relaxing, exotic atmosphere and reputation), and tourism resource (natural attraction, activities offered in area and hospitality). Cultural and heritage, as a crucial a part of the demand for knowledge of the place visited, create the experience of the tourist's visit that permits to possess the power to form the choice to return, recommend and promote the destination as a prominent part of his historical heritage experience (Poletto, 2003). Cultural and heritage-based tourism has long existed, but recent geographical, social, and cultural changes within the main source countries have open on to an increasing number of new niche markets in destination countries, including culture-oriented holidays (Ismail et al., 2014).

Cultural Tourism, has been on a rapid and consecutive rise for many years now and most in order that the European Commission designated 2018 as a Year of Cultural Heritage (Fairley, 2021). Many developing and developed countries have realized that cultural tourism is worth pursuing because it is a high-spending like tourism involving highly educated individuals (Richards, 2014). Cultural Tourism of Bangladesh includes the experiencing of regional or urban or local cultural \& traditional activities such as different types of cultural festivals, cultural food, cultural clothes, religious values, cultural heritage, traditional drama, music and dance, cultural sports, museums etc. It's also encircling the lifestyle, monuments, heritage sites and participation of arts-related activities in Bangladesh. According to Md. Wahidur Rahman (Rahman, 2012), the primaeval culture of Bangladesh, the customs of its people, the traditions, religious values, etc. embodied the means for Cultural Tourism. It is quite possible and very natural to attract any cultural tourist by regional/local cultural activities to a tourist destination with a nice presentation of hospitality.

The extensive nature of the cultural tourism phenomenon has also tended to generate an expanded category of definitions for Bangladesh. Most of these definitions has been formulated for a specific objective, and therefore tend to address only one major aspect of cultural tourism. Nowadays cultural tourism becomes the most popular chapter in the tourism sector. Domestic and international tourists made 192 million trips to visit the UK's cultural, historic and natural assets in 2015 and during their visit; they spent $£ 17.5$ billion (Oxford Economics, 2016). More than a quarter of Europeans (26\%) mention culture (religion, gastronomy, arts) collectively as their main reasons for taking a holiday in 2015, with greater percentages for older and more educated people (Eurobarometer 2016). So the writer of this research tried to formulate all the related contents \& presented some new ideas by drawing a proposed model including with full of explanation about cultural tourism in Bangladesh. The research indicates that there is significant information 
about cultural tourism in Bangladesh; cultural tourists are more likely to use travel information sources, to stay in Bangladesh, to recall the communities they visited, to engage in travel activities and spend money. Consequently, it demonstrates that how much tourists are interested in Bangladeshi culture tourism. The development areas and the value in terms of tourist destination, cultural and social interaction with the host communities of Bangladesh are important.

\section{Tourism}

According to UNWTO, the definition of tourism is basically the activities of a person travelling to and staying in places outside their usual place of residence for less than one consecutive year for leisure, business, and other purposes. Tourism and travel are not the same. To make tourism there must be a translocation of an individual who wishes to travel, using any form of transportation, might even travel on foot. But all travel isn't tourism. Essentially, it refers to all or any or any activity related to the short-term movement of people to locations far from where they typically reside. It is one of the largest industries of the world and thus, the economies of the many nations are driven, to an outsized extent, by their tourist trade. Macintosh and Goeldner (2010) defined tourism as a accumulation of activities, services and industries which deliver a travel experience comprising transportation, accommodation, eating and drinking establishments, retail shops, entertainment businesses and therefore the hospitality services provided for people or groups travelling far away from home.

\section{Culture}

The original meaning of the English word culture was derived from the Latin cultura, in both the literal sense of cultivation (as in "of a crop") and therefore the metaphorical sense of self-improvement (the "cultivation of the mind") (Culture Research Paper 2021). The latter was commonly invoked in 18th-century England pertaining to personal betterment through the refinement of judgment, taste, and intellect; and, by extension, to those activities believed to precise and sustain that sophistication (Williams, 1983). This basic sense underlies the foremost common popular application of the term today, which identifies a selected segment of society as cultural (including, for instance, theatre and art) to the exclusion of all others. Broadly, culture is the social heritage of a group or an organized community or a society. It's a pattern of responses discovered, developed, or invented during the group's history of handling problems that arise from interactions among its members, and between them and their environment. These responses are considered the right way to perceive, feel, think, and act, and are passed on to the new members through immersion and teaching. Culture plays as a determinant of what is acceptable or unacceptable, important or insignificant, right or wrong, workable or impracticable. Culture encompasses all prudent and shared explicit or implicit, norms and values, assumptions, beliefs, knowledge, attitudes, behaviour, dress, and language. 


\section{Tourism and Culture}

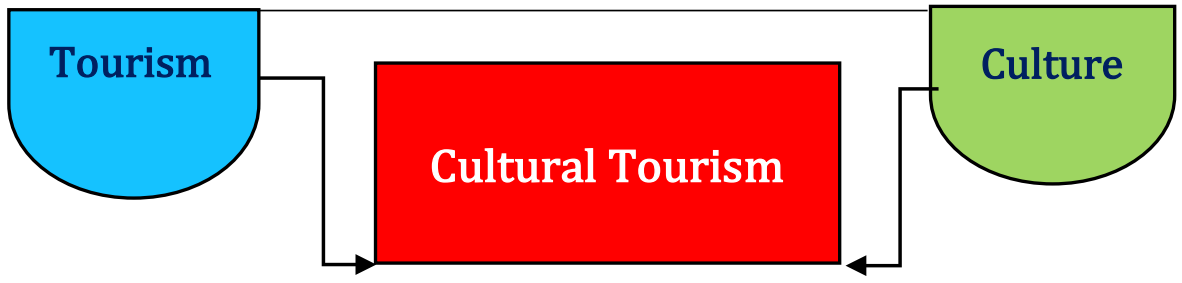

Fig. 1 - Cultural Tourism

Source: Authors

The word both 'Tourism' and 'Culture' are the foremost important terms for Cultural Tourism. These make a broad sense and a selected definition to many researchers. Macintosh and Goeldner (McIntosh \& Goeldner, 1986) stated that Tourism is the sum of the phenomena and relationships growing from the interaction of tourists, business suppliers, host governments and host communities within the process of attracting and hosting these tourists as well as other visitors. On the other hand, many researchers represent the culture with different types of definitions to know its common features. According to Kim Ann, culture is the characteristics and knowledge of a particular group of people, encompassing language, religion, cuisine, social habits, music and arts (Zimmermann, 2017). There is little question that culture is the most interesting and attractive traditional source for a state, region, or country. It stands for the activities of any community or group of people about their tradition, belief, the integrated pattern of human knowledge and behaviour. It also presents the values, outlook, moral goals, principles and traditions shared by any community.

\section{Cultural Tourism}

Cultural tourism may be a relatively new field of study that emerged from vocational education of tourism and culture. The nature of cultural tourism education seems to contribute toward tourism pedagogies, driven by business and cultural considerations. At the same time, it makes tourism education vulnerable to social manipulation by these same forces. The World Tourism Organization (2012) defined cultural tourism as trips whose main or associated purpose is visiting the sites and events whose cultural and historical value has turned them into a section of the cultural heritage of a community and as a form of tourism, it permits tourists to be involved in local cultural related activities like rituals and festivities. It also guides the destination in providing a chance for authentic cultural exchange between locals and visitors. Richards (2011) also stated that satisfaction is considered an important element to sustain the competitive business within the tourism industry. WTO also formulated cultural tourism which incorporates movements of persons for essentially cultural motivations like study tours, performing arts and cultural tours, visit festivals and other cultural events, visits to sites and monuments, travel to study nature, folklore or art, and pilgrimages.

UNWTO adopted this definition during the General Assembly of its 22nd session (2017), that cultural tourism implies a form of tourism activity during which the visitor's essential motivation is to seek out, discover, experience and consume the tangible and intangible cultural attractions or products during visiting a tourism destination. These 
attractions or products related to a group of distinctive material, intellectual, spiritual and emotional features of a society that encompasses arts and architecture, historical and cultural heritage, culinary heritage, literature, music, creative industries and thus the living cultures with their lifestyles, value systems, beliefs and traditions. Cultural tourism is a significant part of tourism concerned with a traveler's desire with a country or region's culture; mainly, it focuses on the lifestyle of the host community, their history, their art and heritage, their religion, and therefore the other components that help to shape their life (Horaira, 2020).

Cultural Tourism is one of the largest commercial sectors in the world. Cultural activities including folklore or art, traditional dance, music and drama also are of much interest to domestic and foreign tourists.

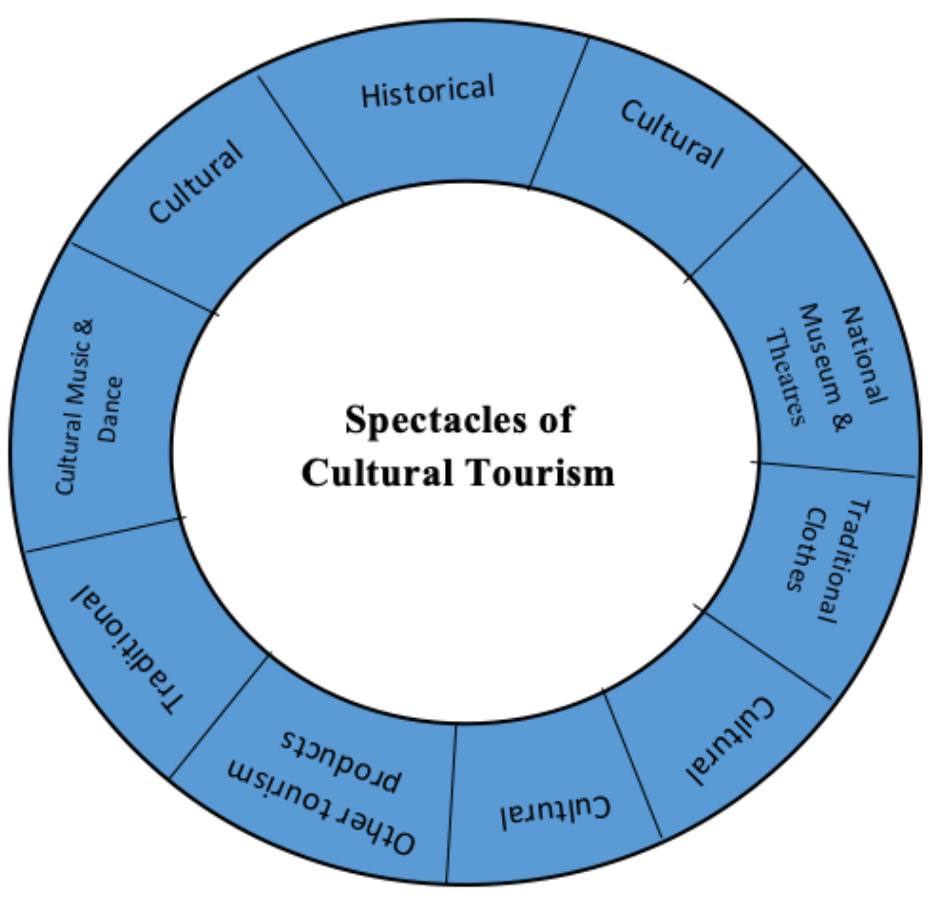

Fig. 2 - Spectacles of Cultural Tourism

Cultural tourism is a subset of tourism and culture and its elements can be mentioned as the spectacles of cultural tourism which creates a bond of relationship in a big circle (Fig 2). It is simply known as the form of tourism concerned with a region or country's culture, represents the history of the nation \& the culture of those geographical areas, the lifestyle of those communities, their religious values, art, and architecture and includes other elements (service provider like hotels, motels, airlines, host community etc.) that helped to shape their way of life. It comprises tourism in rural areas, particularly historic or large states and their cultural morals, norms and facilities such as festivals, food, dresses, music, dance, heritage, museums and theatres. It also can include tourism in urban and suburban areas showcasing the traditions of different indigenous cultural communities, and their values and lifestyle.

\section{Tourism in Bangladesh}

Bangladesh is located within the northeastern part of South Asia. The magnificent Himalayas stand away to the north, while within the south lays the Bay of Bengal. There is 
a West Bengal approximate the west and within the east lie the hilly and forested regions of Tripura, Mizoram (India) and Myanmar. These picturesque geographical boundaries frame a low lying plain of about 1,47,570 square kilometres crisscrossed by abundant rivers and streams. Mighty rivers are the Padma (Ganges), the Brahmaputra (Jamuna) \& the Meghna and also the Karnafuli.

Bangladesh is plaited together by quite 700 rivers, producing a beautiful lush landscape with more reminder green than one ever imagined. Travelling by boat may be a way of life here, and provides an exquisite opportunity to ascertain the country from a strange angle. Bangladesh is the most densely populated country in the world but once slowly floating downriver on a bit wooden rowboat, it's easy to imagine you've got it all to yourself.

Bangladesh is a home of many tourist attractions, including archaeological sites, historical mosques and monuments, the longest natural unbroken beach of the world, green landscape, swamp forests and wildlife, hill tracts with rolling tea gardens and tribes. Tourists find the rich flora and fauna and vibrant tribal life very enchanting. Each and every region of the country offers distinctly different topography, flavours and food. It is also the home to the Royal Bengal Tigers, freshwater pink dolphins, historical temples made from the red earth.

Besides Cox's Bazar the Longest Unbroken Sea Beach of the world, the largest mangrove forests and tigers of the Sundarbans, Buddhist remains at Paharpur and therefore the 15th-century Sixty Dome Mosque and mausoleums of Bagerhat, both of which are UNESCO World Heritage Sites (Pathfriend, 2020). While modern Bangladesh is majority Muslim, its hill tracts are still home to Buddhist and Christian indigenous peoples, while temples in Dhaka and beyond attest to the influence of Hindu culture on the country. Bengali culture is famously renowned in the world for its welcoming and hospitality.

The tourism sector can help to flourish the economy of Bangladesh. By ensuring proper improvement of this area, it's potential to earn a great deal of foreign currency which can donate to the expansion of the economy of the country. The tourism industry also offers ample employment opportunities for the people that are directly or indirectly involved in this sector, since it's a service-providing sector. The joblessness problem of the country will be reduced partly to develop necessary infrastructures of this sector. It'll help to extend household income and also because the revenue collection of the government will rise consistently (Latif et al., 2016).

According to the WTTC, the direct contribution of travel and tourism to Bangladesh Gross Domestic Product (GDP) is forecast to grow by $2.0 \%$ pa by 2025 (2015). Certainly, Bangladesh has distinctive tourism resources and has the potential to develop tourism as a crucial means for its social and economic development. Sound and evidence-led tourism policies and political support alongside the participation of the private and voluntary sector are essential for Bangladesh to become a successful and sustainable tourism destination.

\section{Cultural Tourism in Bangladesh}

Bangladesh is historically very rich with authentic cultural amusement activities and its culture is thoroughly reflected in its lifestyle, art and architecture, language and literature, music, dance, painting and clothing. There are three primary religions of Bangladesh (Hinduism, Buddhism and Islam) that have had an excellent influence on its culture and history. The people of Bangladesh's way of life structure the culture of Bangladesh. The 
country features a diverse culture that has evolved over time with influences from diverse social groups (Kiprop, 2018).

The culture of Bangladesh refers to the way of life of the people of Bangladesh and it evolved over the centuries and encompasses the cultural diversity of several social groups of the region (Culture \& Traditions 2016). The Bengal Renaissance of the 19th and early 20th centuries noted Bengali writers, authors, scientists, researchers, thinkers, music composers, painters, and filmmakers have played a serious role in the development of Bengali culture. It's illuminated in various forms including music, dance and drama; art, architecture and craft; folklore; languages and literature; philosophy and religion; festivals and celebrations; moreover as in a significantly distinct cuisine and culinary tradition (Bengal Renaissance 2021).

Therefore, Bangladesh is able to offer desirable tourism product services and experiences with infinite demands for finite government and non-government resources. As a part of tourism, cultural tourism is making a good demand \& playing a great role in developing the economic sector in Bangladesh. The journey of people to specific cultural destinations that offering our Bangladeshi cultural attractions, including folklore, historic sites, artistic, cultural events and shows, with the aim of disseminating and same time acquiring new knowledge and experiences that meet the intellectual needs and individual growth of the traveller. As a form of tourism, it allows tourists to be immersed in local cultural related activities such as rituals and festivities. It leads the destination in providing opportunities for authentic cultural exchange between locals and visitors.

\section{Cultural Attraction for Tourists}

There are lots of cultural festivals, traditional music and foods, clothes in Bangladesh. Every single thing has related to Bangladeshi cultures. The cultural festivals, cultural music, cultural clothes and traditional foods of Bangladesh are discussed below:

\section{Cultural Festivals}

Bangladesh is also known as a land of festivals. There are different forms and types of festivals are celebrated here in Bangladesh whereas some of the festivals have religious and cultural values, some of the festivals have traditional and historical backgrounds, some of them are celebrated as national festivals. Most of the national festivals of Bangladesh are associated with the history of Bangladesh.

\section{Symbolism}

Bangladesh has become an independent country in 1971. The 26th March is celebrated as Independence Day and 16th December is the Victory Day of Bangladesh. The symbol of the Bangladeshi flag is started with red \& green colours where green stands for beautiful green nature and red stands for the sun. The major people of Bangladesh are used to talk with the Bengali Bangla language. The national anthem was written by a famous \& very popular poet around the world and his name is Rabindranath Tagore.

\section{Pohela Baishakh}

'Pohela Baishakh' is known as the New Year of the traditional Bengali calendar and the word 'Pohela' means 'first' and 'Baishakh' means the first month of the traditional Bengali calendar. Every year Pohela Boishakh is celebrated on the 14th of April. On this day, people enjoyed their time with everyone especially with friends, relatives, neighbours, 
family etc. They eat traditional Bengali food, wear cultural dresses, and attend the Bengali fair and cultural program.

\section{Ekushey February}

The 21st of February is known as the Ekushey February or Shaheed Dibas (Martyrs' Day) of Bangladesh. This is only one nation in the world that fought for its mother language (Bangla). Now February 21 has been celebrated as the international mother language day since 2000 by UNESCO in recognition of the sacrifices made by the people of Bangladesh for their mother tongue (International Mother Language Day 2021). 21st February is one of the most memorable annual day in the history of Bangladesh (Travel-News, 2020). The people of Bangladesh commemorate this national day with a public holiday for the martyrs who sacrificed their life and protested to protect 'Bangla' as the national language in 1952 at the time of the Bengali Language Movement.

\section{Eid-ul-Fitr}

The majority of the people of Bangladesh are Muslims but the enjoyment and happiness of the occasion are spread everywhere the people of Bangladesh no matter their religion. Eidul Fitr is widely celebrated in Bangladesh with great radiance. Eid-ul-Fitr is the first day of the Arabic 'Shawal' month. After the end of the month-long of fasting, Muslims celebrates Eid-ul-Fitr by performing the obligatory Eid prayers on the morning of Eid. During the celebration people wear new clothes, prepare traditional dishes, visits friends and relatives, exchange greetings, it is one of the most important festivals of Bangladesh also as for the Muslims.

\section{Eid-ul-Azha}

Eid-ul-Azha is one of the most important religious festivals of the Muslim community in Bangladesh. Eid-ul-Azha is celebrated with the spirit of sacrifice on the 10th day of the month of the lunar Islamic calendar after the holy Hajj, the annual pilgrimage to Mecca in Saudi Arabia. Muslim community of Bangladesh offered special Eid prayers in the morning seeking divine blessings, peace and prosperity. After the Eid prayers, people sacrifice animals such as cows, goats, and sheep on a sacred day. A large portion of the meat of the sacrificed domestic animals is shared with the poor people and with the relatives and neighbours. During Eid festivals, people of all professions and classes leave behind their differences and exchange greetings with one another. People from the big cities attend their ancestral roots in the villages to share the joy of the festival with friends and relatives.

\section{Durga Puja}

Durga Puja, the most important and popular religious festival of Bengali Hindus is celebrated widely across Bangladesh. It is also an event for reunion and rejuvenation, and a celebration of traditional culture and customs besides being a religious festival for the Hindus. Every year Durga Puja is celebrated in the Bengali month of 'Ashwin' (September- October) which is also a symbol to respect the women like as a mother. Durga Puja is a grand cultural celebration in the capital city of Dhaka and is held in numerous pandals, but the most important celebration takes place at Dhakeshwari Temple where thousands of devotees and observers visit the premises for four days. An exclusive 'Nouka Baich' (boat race) on the Buriganga River is arranged, attracting a large crowd. 'Bijoya Dashami' the last day of the festival is a public holiday in Bangladesh. The 'Dashohara 
Mela' is held on today and effigies are paraded through the streets of 'Shankhari Bazaar' in Old Dhaka in loud, colourful processions before being immersed into the rivers. The Hindu community assembles at the fair wearing new dresses and exchanges greetings and the juveniles look over their elders to crave their blessings. Muslim community participates in the secular part of festivities in celebration of Bengali solidarity and culture. Food and clothes are distributed among the poor on the occasion.

\section{Pohela Falgun}

According to the Bengali calendar 'Pahela Falgun' is the first day of the month of Falgun (spring). It is celebrated in the most awaited season of spring. Pahela Falgun brings new life to the cultural festivals of the Bengali speaking people. Nature takes a green look during this season, with new leaves in the trees; butterflies and bees flying from flower to flowers, blooming in the garden. People celebrate the day amidst festivity at the end of a comparatively lazy winter. Wearing traditional yellow coloured sarees, young women welcome the arrival of the spring. In the day, women look charming with yellow 'Saree' and wear different types of ornaments made from lovely yellow flower gardenia and men in 'Fotua', and 'Punjabi'. The fairs are held in almost every part of the country. There also are different entertainment takes place throughout the country, like 'Pala Gan', 'Gazir Gan', and modern music concerts.

\section{Nabanna Utshab}

'Nabanna Utsab' (the festival of new harvest) is widely known by the rural people across the country during the Bengali month of Agrahayan (Nov-Dec). The occasion is very significant for farmers of the country as they begin harvesting new crops on the very first day of the Bengali month of Agrahayan after waiting for months. Traditionally poets, painters, musicians, 'Baul's (folk singer) and people from all walks of life come together at this festival. Nabanna Mela (fair) is usually held in the countryside. Farmers return home with a lot of golden paddies. This is often a joyous time in the villages.

\section{Poush Parbon}

'Poush Sankranti' is an annual celebration in Bangladesh and also called 'Makar Sankranti', which means the end of the Bengali month of 'Poush' (Sankranti means 'end' in Bengali). 'Poush Sankranti' is the first Bengali event in the Gregorian calendar that culminates on 15 January. The main attraction of the festival is traditional 'Pitha's (cake) and the tradition also includes the exchange of dishes and greetings among relatives, friends and neighbours.

\section{Shakrain}

'Shakrain' is a 'Kite Festival' celebrated at the end of 'Poush', the ninth month of the Bengali calendar (January 14 or 15 in the Gregorian calendar) at 'Old Dhaka Town' of the capital city Dhaka and is one of the oldest annual festivals of Bangladesh (Shakrain Young Observer 2018). The festival is a very popular and very important event in Bangladeshi culture. 'Shakrain Festival' is regarded as a symbol of unity and friendship in Bangladesh. Different types of colourful kites are flown high from the rooftops around the area within the afternoon and it often takes the form of kite fighting, in which participants try to snag each other's kites as part of different organized competitions. During the evening breathtaking fireworks illuminate the sky of old Dhaka. Peoples gather on the roofs and celebrate the occasion with music, dancing and enjoying traditional cuisines. 


\section{Cultural Music}

Bangladesh features a very rich musical heritage since music has always played a crucial role in the lives of the people. In past, the song was usually linked to prayer and this will still be seen somewhat today in the singing of folksongs that always praise certain gods and their creation. Music, a part of intangible cultural heritage, including classical, folk and modern are often a major source of amusement for foreign tourists. Bangladeshi classical music is enrooted from the remote- past in terms of vocal and instrumental. Bangladesh is an extraordinary abundance of ethnic and traditional folk songs that blossoms in the spiritual lyrics of Lalon Shah, Hasan Raja, Romesh Shill and many other anonymous lyricists. The musical tradition of Bangladesh is significantly lyrics-based and the 'Baul' genre is a distinctive form of Bengali traditional folk music. Besides, there are a notable number of unique musical traditions that exist including 'Gombhira', 'Bhatiali' and 'Bhawaiya', varying from one region to subsequent. Bengali musical sphere is enriched with widely popular Jari, Shari, Bhatiali, Murshidi and other forms of folk songs. Deeprooted emotional ingredients in these mystic lyrics that mainly speak of universal humanity, love, affection, and therefore the existence of omnipresent God, can easily attract tourists, both domestic and foreign.

\section{Traditional Dress}

Bangladesh has its own cultural dress and people have unique dress preferences. Most of the males traditionally wear 'Panjabi' on religious and cultural occasions, and females 'Saree' is the main and traditional dress in Bangladesh. Most significantly, each particular fabric contributes to representing the culture and traditional art in Bangladesh. Traditional weavers from Sonargaon, Dhaka is renowned for producing exquisite 'Dhakai Jamdani' saree and the 'Jamdani' is recognized as an intangible cultural heritage by UNESCO. 'Jamdani' cloth is made by designing on 'Muslin'. 'Muslin' is not just a piece of fabric; it is inseparably connected to the history, culture and heritage of Bangladesh (Sonargaon, the birthplace of Jamdani - Jamdani Festival 2019). A survived branch of Muslin is known as 'Jamdani'. Recently, this rare fabric 'Muslin' has secured Geographical Indication (GI) recognition as a product of Bangladesh.

\section{Traditional Food}

Bangladeshi cuisine is distinctively influenced by its landscapes and also the resources produced from the land, the rivers and the sea. The country is extremely embodied by lowlying altitude and an abundance of water, particularly the monsoon. Besides the land and geography, Bangladeshi cuisine has been heavily moulded on Dhaka's historical trade routes and many of the predominance's. Particularly the Mughals brought with them Turkish and Persian techniques and foods. Bangladeshi foods mainly reflect the country's culinary past and its rich heritage influenced by the predominant cultures and the cuisine is decidedly South Asian in nature. Therefore the cuisine is unique in its bountiful tradition of fish and a variety of often hot pastes made from ground roots, spices and chillies. Rice is a must on the dinner plate of a Bangladeshi is typically eaten with two or three items such as stuff prepared with vegetables, fish, meat, lentils, dry fish (locally called 'Shutki'), etc. The most traditional food of Bangladesh is 'Pantha Ilish' and Bangladeshis can't imagine the celebration of 'Pahela Boishakh' without 'Pantha' (Pantha is made from the rice after putting water on it for some time) and Ilish' (the 'Hilsa' fish, called 'Ilish' in Bengali). 


\section{Cultural Sports}

A nation's own culture is the true identity of its ethnicity and culture is the heritage of that nation. Cultural games and sports is an integral part of the culture of Bangladesh and a very popular source of amusement. There are many types of local games in Bangladesh. 'Ha-dudu' (Kabaddi), 'Dariabandha', 'Kanamachhi', 'Gollachut', 'Kho Kho', 'Lathi Khela', 'Boli Khela', 'Nouka Baich', 'Sharer Lorai' are examples of Bangladeshi cultural sports. Bangladesh's national sport is Kabaddi. But the most popular game in the country among the generation is cricket and football.

\section{Cultural Heritage Sites}

The cultural heritage of Bangladesh is influenced by the interventions of many ancient regimes and found in the remnants of pre-historic civilization as well as other magnificent monuments of a different era. UNESCO has recognized two cultural and one natural World Heritage Sites in Bangladesh and these are the Historic Mosque City of Bagerhat, Ruins of the Buddhist Vihara at Paharpur, and the Sundarbans. Additionally, there are five properties included in the UNESCO Tentative List. These are archaeological remains of Mahansthangarth, The Lalmai-Mainamati Group of monuments, Lalbagh Fort, Halud Vihara, Jaggadala Vihara (UNESCO, Tentative Travel Lists 1999). Besides Bangladesh has notable heritage sites among other the subsequent Ahsan Manzil, Sonargaon, Wari Bateshwar, Mainamati, Paharpur, Soto Sona Masjid in Chapai Nawabganj, Kantajew Mandir in Dinajpur, and Jatiyo Shahid Minar, Martyred Intellectual Memorial, National Poet's Grave, Bangladesh national parliament complex in Dhaka, Bahadurshah Park, Curzon Hall etc.

\section{Role of Cultural Tourism in Bangladesh}

Cultural tourism is one of the potential and significant sectors in the tourism sector of Bangladesh. Cultural and heritage-based tourism is a fast-growing section of the tourism industry, inventing and sustaining jobs also providing opportunities for marginalized groups (Horaira, 2018). It also strengthens social bonding and creates networks among the social groups that come together for a mutual and collective purpose. Cultural tourism basically takes place with the intention of travelling to seeking knowledge and experience of the places that authentically represent the stories and folks of the past and present. It includes irreplaceable historic, cultural and natural resources. Cultural tourism has various forms like cultural villages, cultural routes, art, crafts and native dances that are offered to tourists. It gives clear ideas to the tourists regarding the various touch of life-style and the difference in the culture of people. Bangladesh has enormous cultural attractions which are considered attractive to visitors (Howlader, 2016).

A number of these are the lifestyle of the tribals of hill tracts and other ethnic groups of the country, historic and archaeological sites like Sonargaon, Mynamati, Paharpur, Mohastangar, Shat Gambuj Mosque, World War II Cemetery, Batali Hill, ancient mosques, temples, church, pagoda, ethnological museums, different rajbari, historical places, ancient buildings, different monuments, different religious traditions and festivals, music and cultural events etc. The man-made cultural resources for tourist attractions in Bangladesh are historical and archaeological sites, diverse cultural infrastructure, different art and crafts that link the whole country together. Bangladesh is a small country having at least 55 ethnic communities which is quite significant in the world and interestingly a number of them still follow lifestyles that have remained intact for hundreds of year. Moreover, the people of Bangladesh are very friendly and simple which 
are very popular with both international and domestic tourists. Above mentioned factors can make Bangladesh a preferred destination for cultural tourism in the world.

\section{Cross-Cultural Connection}

Cultural tourism considers not only the aspects of the physical environment but also the dimensions of the social and cultural environment of destinations. Nowadays, crosscultural psychology also playing a significant role in identifying the substantive dimension of cultural tourism in Bangladesh. In recent years the interest in cultural tourism has boomed, emerging as a large and growing section of the tourism industry (Reisinger \& Turner, 2011). Still, in spite of its global and local implications, the area has not been adequately explored by tourism researchers, who first studied cultural tourism by measuring visitors to cultural attractions like museums, festivals, fairs, exhibitions, plays, concerts, dance performances, etc.

A destination value chain is unfurled to capture the possible impact of culture and cultural values on tourism behavior (Weiermair, 2000). Cultural norms have an impact on both tourists' expectations and their perceptions of received service quality for any of the service elements often applied in tourism analyses. Tourism service encounters happen within the context of a tourism culture which is formed by four components such as the national or regional settings of the tourist and also the host region, and different subcultures of the tourists' and also the organizational culture of tourism entities within the tourism receiving region.

Satellite, social media (Facebook, Twitter, Instagram, Snap Chat, and YouTube), TV shows, movies, internet web browsing etc. are the popular medium for cross-cultural exchange. Sometimes it is good for knowledge, experience and enjoyment but adaptation and popularisation of foreign culture are often a threat to the indigenous cultural tourism of Bangladesh. Geographically unique Bangladesh has its own proud history of the people, language, music, arts, drama, festivals, foods and so on. But sometimes it seems like the culture and tradition of Bangladesh may lose their cultural identity due to the influence and intervention of neighbouring countries' culture and Western culture. Culture and cultural tourism in Bangladesh should be one of the first concerns for all the stakeholders of Bangladesh.

\section{Impacts of Cultural Tourism in Bangladesh}

The culture and heritage of a country express the values of its historical importance (Wickramasinghe \& Kumara, 2021). Cultural heritage is developed paralleling with a specific scale of meanings and values (Corsale, 2017). Cultural tourism occupies a large scale market share as compared with other segments within the tourism industry. Cultural tourism activities may include all products related to public archaeological promotion including a visit to archaeological sites and museums, interpretation of inscriptions, reenactments of historical events and therefore the re-discovery of indigenous cultural festivals. Cultural tourism can bring many economic, social and environmental benefits particularly in rural areas and developing countries compared to mass tourism which is redundant to negative effects (Chandra \& Roy, 2015). The most common positive impacts of tourism on culture comprise growing cross-cultural interaction such as understanding, maintaining and keeping local culture, arts, crafts and traditions as well as empowering host communities, and strengthening cultural values (Shahzalal, 2016). Tourism can only be sustainable if it is carefully driven and cut down the possible negative effects on the 
host community and therefore the environment should not be sanctioned to outweigh the economic benefits.

\section{Economic impact}

Tourism can provide direct jobs to the community, like tour guides and hotel housekeeping (Chandra \& Roy, 2015). Indirect employment is basically created through other industries like agriculture, food production and retail. Infrastructure development and visitors' expenditure generate income for the local community and result in poverty alleviation. The positives of economic impact such as the society around the destination have better income because it generates new businesses, creates employment opportunities, develops infrastructure and available transportation facilities and the negative such as higher cost of goods and services, routine expenses, more expensive of property, the coming of the nonresidences who take benefits of the local community (Pramanik \& Ingkadijaya, 2018). According to WTTC (2020), Travel \& Tourism (inclusive its direct, indirect and induced impacts) calculated for 1 in 4 of all new jobs created across the globe, $10.6 \%$ of all jobs (334 million), and $10.4 \%$ of the world GDP (US\$9.2 trillion). The international visitor spending amounted in meantime about US\$1.7 trillion in 2019 (6.8\% of total exports, $27.4 \%$ of world services exports). Whilst the world economy grew by $2.5 \%$, GLOBAL DATA 2019 Travel \& Tourism grew significantly more at 3.5\% in Bangladesh.

\section{Social impact}

Social and cultural impacts of tourism are the process through which tourism is contributing to changes in societal value systems, individual behaviour, moral conduct, creative expressions, family relationships, collective lifestyles, traditional ceremonies and community association (Pizam \& Milman, 1986). Positive socio-cultural effects of tourism as recognizing and experiencing different cultures, contributing to the formation of crosscultural diversity, tolerance and peaceful environment, recognition and appreciation of emerging cultural values and traditions and the negative socio-cultural impacts as disruption in the mother language, change and emulation in local identity and values, commodification of culture, loss of originality, disruption of traditional lifestyle and hospitality, social ties and weakening of family bonding and cultural conflicts between tourists and the local community (Ozturk et al., 2015). For instance, these are the effects on the people of host communities of their direct and indirect connection with tourists. In addition to the revenue, tourism can bring a real sense of pride, identity to communities and it allows them to look at their history and community identity. This helps the local residents to maintain their traditions and culture in Bangladesh (Chandra \& Roy, 2015).

\section{Environmental impact}

Typically tourism industry is an environment-friendly industry that belongs to low resource consumption and small environmental destruction. However, there is still a great deal of "non-ecological" phenomena and certain energy consumption and pollution emission, which have certain impacts on the ecological environment (Zhao \& Min Li, 2018). The positive impacts of tourism development have the potential to form beneficial effects on the environment by contributing to environmental protection and conservation and the same time can gradually demolish the environmental resources on which it depends (Carol \& Nkamnebe, 2019). The improper arrangement of infrastructure of a country seems to comprehend negatively by the international visitors to choose a destination (Henderson, 2011). Most of the traditional lifestyle and cultural beliefs in tourism locations in different 
parts of the world often maintain a balance between nature and human activities by trying as much as possible not to harm nature because of conserving biodiversity and natural ecosystems. Their beliefs and values are that nature is life which provides them with a direct connection with their ancestors. With the introduction and influence of the latest or outside cultures, however, it's going to erode such practices which will ultimately end in the degradation of natural ecosystems. Tourism provides financial support for the conservation of ecosystems and natural resource management, making the destination more authentic and desirable to visitors for tourism in Bangladesh.

\section{Future Prospects of Cultural Tourism}

The present trend of tourism across the world is to enjoy the culture and tradition of rural habitation. As a matter of fact, cultural tourism products comprise both tangible and intangible heritages, which are major attractions to foreign tourists. Bangladesh is full of multifaceted cultural and traditional attractions and its inherent heritage is abundantly reflected through its architecture, literature and cultural activities including dance, drama, music and painting (Husain, The arts of Bangladesh). Bangladesh has been a meeting place of diverse races and manifested in a junction of civilizations influenced by great mainstream religions exemplarily Buddhism, Hinduism, Islam, and Christianity. As a matter of fact sculpture, tapestry, engravings have been developing along with the mainstream contemporary art and drama mainly of indigenous origin and these have distinct features of intangible heritage.

Inherently Bangladesh is having its own novelties in drama, pantomime, puppet, theatre, caricature, acrobatics and circuses that contribute to intangible cultural heritage. Besides, Bangladeshi music has developed through centuries significantly in the three mainstreams genres folk, modern and classical. Folk, tribal and classical are the prominent forms of dances that also fall under the intangible cultural heritage resources.

\section{Proposed Conceptual Model for Cultural Tourism Development in Bangladesh}

There are quite a few management models are available and these models are continuously developing through model innovation (Birkinshaw et al., 2008). Management models utilized in European countries like France, Germany, and Spain enhanced their national competitiveness within the tourism sector (Papadopoulou, 2020). Bangladesh, being new in the tourism industry in terms of its exposure as a cultural tourist destination in the world tourism arena, should make the best effort for finding out some appropriate techniques for marketing its tourism products. Based on the literature and to serve the purpose of this research has been developed by the following conceptual model (Fig- 3) for giving a clear idea generation. 


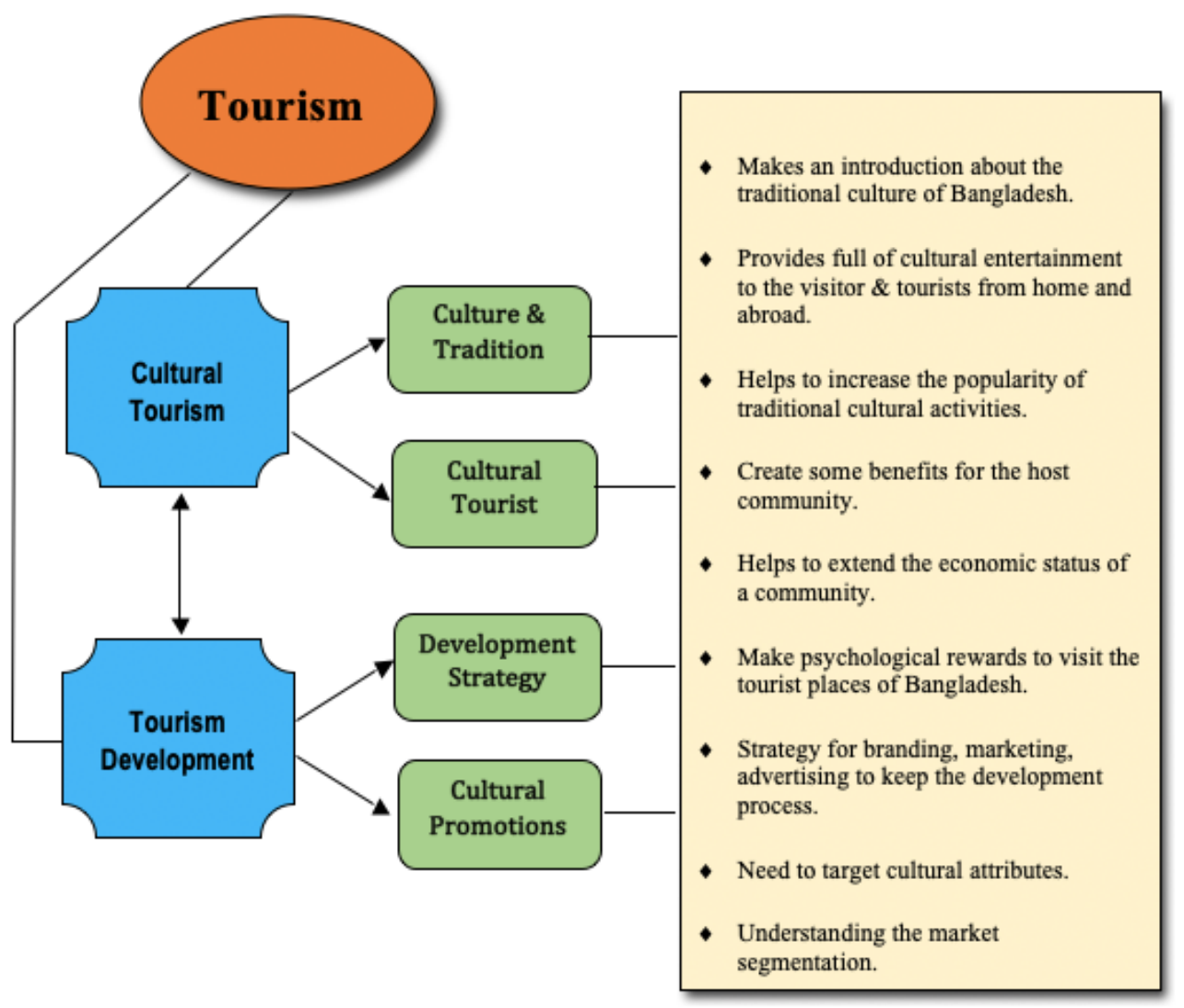

Fig. 3 - A model for Cultural Tourism Development in Bangladesh

By analyzing the 'Conceptual Model for Cultural Tourism Development in Bangladesh', the researchers found two sub-points of it (Fig 3). One is the 'Cultural Tourism' and another one is the 'Tourism Development' of Bangladesh and which are directly and indirectly involved to provide cultural entertainment to the visitors and tourists from home and abroad (Fig 3). On this proposed model cultural tourism has been categorized into two sub-points. The first one is culture and traditions and the second one is the cultural tourist. The tasks of culture and tradition are to introducing Bengali culture, providing cultural entertainment and try to increase the popularity of cultural tourism to all.

The other part, the development process has shown also by two sub-points. The first one is to look forward or build up the strategy of cultural development and also determining the cultural promotions. The strategy of cultural development has some strong things which are needed to be focused on. Such as the branding strategy, selling strategy, marking strategy, advertising strategy etc. Without a good or strong strategy, it is impossible to keep the development process of cultural tourism in Bangladesh. Cultural promotions need some platform to complete some tasks like targeting the cultural tourist, market segmentation, making promotional events etc.

Nowadays the development of cultural tourism is very important for Bangladesh because the popularity of Bangladeshi cultural tourism to all classes of people in the world will help us for our economic growth. Cultural tourists and visitors from home and abroad 
help to increase our economic status and GDP in Bangladesh. Not only that, it also increases the benefits for the host community like the airlines, travel agencies, hotels etc. So it's very clear to utilize that cultural tourism in Bangladesh is new hope for the country.

\section{Methodology}

Qualitative Research for the knowledge professional is then a useful start line, and rapidly becoming a typical point of reference, for researchers who aim to undertake nonquantitative research (Terras, 2006). There are five, not necessarily ordered or sequential, components in qualitative research designs, however, they are presented depends upon the research philosophy and theoretical framework of the study, the methods chosen, and therefore the general assumptions underpinning the study (Maxwell, 2008). Research components to data collection were literature review, participant observation and informal interviews, following a methodological triangulation (Berg \& Lune, 2012). This study was primarily qualitative in nature, and the required data and information were collected through document analysis. This research article was specially prepared from the conceptual ideas, secondary data and information and exploratory field observation. For this purpose, a radical literature review had been conducted. So as to get reliable secondary data various journals, periodicals, books, newspaper articles, acts, regulations, policies of Bangladesh, websites, annual reports, papers of various agencies were consulted carefully. The foremost important step of primary data collection was from the overall academic knowledge and also from the focus group discussion such with the local community people and with the tourists.

\section{Analysis, Discussion and Recommendation}

Culture and tourism are both observed as significant operators for the regional economy which even have a variety of other desirable effects (Richards, 2010). Tourism has long been seen as a source of providing employment, particularly in areas where few alternatives exist. Developing tourism i.e. related to culture intent to produce income to support cultural facilities, and by delectation regional culture, tourists become more responsive to regional distinctiveness. Culturally interested tourists also tend to visit distinctive destinations where other tourists rarely go, helping to spread tourism to new unrevealed destinations. The support offered to local culture also encourages the local community to value and preserve their culture also as boosting them renewed pride within the locality (OECD, 2008). Cultural tourists are seen as high spending tourists with a real interest within the culture of the destinations they visit, which helps to form this type of tourism more sustainable.

Cultural tourism can play a significant role in the development of the travel and tourism industry of Bangladesh. Cultural tourism based on tangible and intangible resources plays an important medium in revitalizing and conserving cultural traditions because these can attract tourists significantly. Intangible heritage components have a significant impact on communities that connects and consolidate community members in terms of their attitude, achievements and their uniqueness. Intangible cultural heritage is the immaterial manifestation of culture, represents the variability of the living heritage of humanity additionally as the most significant vehicle of cultural diversity (Lenzerini, 2011). According to Howlader (2016), intangible heritage plays an inseparable part in identifying a community and it is an effective way for transmitting knowledge to younger generations. 
For a country like Bangladesh where culture and tradition are unique with long historical background, the installation of adaptable technology is necessary for their conservation and preservation.

To promote our Bangladeshi cultural tourism, we also need to focus on a strong strategy that will combine many strategic phenomenons such as marketing strategy, a good selling strategy, advertising strategy, branding strategy, etc. Before making this strategy we need to thoroughly study our tourists, especially cultural tourists. A tourist who has deep cultural experiences can be simply defined as a cultural tourist. After targeting the cultural tourists we also need to determine the cultural promotions of Bangladesh. So, a promotional strategy of cultural tourism in Bangladesh will be a new truing point that will help increase the popularity of Bangladeshi tourism worldwide. To build the brand of cultural tourism in Bangladesh can be presented by a new brand pyramid. On this pyramid, the first step is cultural attributes that mean knowing the major characteristics of cultural tourism in Bangladesh. The second step is the demand for cultural activities means what type of entertainment cultural tourists are demanding for visiting Bangladesh. The third step is about the psychological benefits which mean knowing the psychological rewards or emotional benefits of cultural tourists in Bangladesh. Forth one is about cultural brand value, likes to know about the value of cultural tourism of Bangladesh. The last one is the cultural brand essence of Bangladesh by knowing the most essential part of cultural tourism.

By analyzing the data and information here the researchers also found that the atmosphere attributes were suggested to be more significant in affecting the overall tourists' satisfaction than other attributes such as destination environment and cultural tourism resources of Bangladesh. The cultural representative enough to embrace their unique art and attractions, local handicrafts, traditional architectures, and natural sceneries, as part of tourism resource and atmosphere attributes for the cultural tourism attraction in Bangladesh.

Different awareness programs on sustainable tourism can be introduced among the local community. Bring in sustainable technology to tourism production. Training programs for local communities and other stakeholders on sustainable tourism production and business can be established. The enhancement of public and private investment in terms of infrastructure development, preservation and protection to the tangible and intangible tourism sites can be encouraged. Promoting 'community ownership' of cultural heritage can be done through awareness building. Ensuring sustainable development and same time resisting vandalism by building awareness among local communities. Enhancing investment on advertisement of cultural tourism activities such as heritage, relics, festivals, lifestyle, craft villages, gastronomy etc. through electronic and print media, so that tourists get more attention and get attracted. Local guides should be equipped with professional cultural knowledge through a training program so that they can interpret their deep understanding of the local culture to visitors. Training courses on management skills, environment protection, and technical application, legal updates, etc. should also be provided to business owners, employees who are working in the tourism industry and even staff of government authorities, etc. Extending education about culture and heritage to all levels of society particularly to the younger generation, so that they can get the opportunity to develop broader theoretical knowledge and practical skills in cultural professions. 


\section{Conclusion}

Culture is an important part of the tourism product and is one of the main factors that can improve the competitiveness of a tourism destination. It encourages local communities to explore their culture and boost economic growth, developing culturally geared tourism programs; encourages destinations to celebrate and promote what distinguishes their communities for an authentic cultural exchange between locals and visitors. As a part of tourism, cultural tourism is making a good demand and playing a great role for developing the economic sector of our country. The journey of people to specific destinations that offering our Bangladeshi cultural attractions, including historic sites and artistic and cultural events and shows, with the aim of acquiring new knowledge and experiences that meet the intellectual needs and individual growth of the traveller.

\section{Limitation of the Study and Future Direction}

This overall study was prepared primarily based on secondary information sources and exclusively based on the cultural tourism sector. It had been difficult to collect relevant information as only a little literature, and sources related to the cultural tourism of Bangladesh was found. However, considering current literature future studies can be conducted from different perspectives of cultural tourism in Bangladesh. Particularly the growing demand towards innovation and technology-enhanced cultural tourism experience require more specific empirical researches with quantitative tools and analysis. Moreover, future researchers are also recommended to conduct comparative studies considering exploration of cultural tourism dilemmas.

\section{References}

Banglapedia. (2021). Bengal Renaissance. Retrieved May 18 2021, from https://en.banglapedia.org/index.php/Bengal_Renaissance

Berg, B. L., \& Lune, H. (2012). Qualitative research methods for the social sciences. Pearson.

Birkinshaw, J., Hamel, G., \& Mol, M. J. (2008). Management innovation. Academy of Management Review, 33(4), 825-845.

Boit, J., \& Doh, M. (2014), "The Role of Destination Attributes and Visitor Satisfaction on Tourist Repeat Visit Intentions: The Case of Lake Nakuru National Park , Kenya" available https://scholarworks.umass.edu/cgi/viewcontent.cgi?article=1087\&context=nerr. (accessed 17 September 2021).

Carol, A., \& Nkamnebe, A. D. (2019). Effect of Tourism Consumption on Ecological Development of Host Communities in Cross River State, Nigeria. International Journal of Research and Innovation in Applied Science (IJRIAS), IV(X), 44-51.

Chandra, R., S., \& Roy, M. (2015). Tourism in Bangladesh: Present status and future prospects. The International Journal of Management Science and Business Administration, 1(8), 53-61.

Culture \& Traditions. (2016). Retrieved May 18 2021, from https://bangladesh.uz/culturetraditions.

Daily Observer (2018), Shakrain, available at: https://www.observerbd.com/details.php?id=117225. (accessed 30 July 2021).

Dong, T. B. (2020). Cultural tourism: An ethnographic study of home stay in Briddim Village, Nepal. The Gaze: Journal of Tourism and Hospitality, 11(1), 10-36. 
Economic Impact Report. Economic Impact | World Travel \& Tourism Council (WTTC). (2015). Retrieved June 17 2021, from https://wttcweb.on.uat.co/Research/EconomicImpact.

Escudero, G. L. A. (2018). Realities and problems of a major cultural tourist destination in Spain, Toledo. PASOS. Revista De Turismo y Patrimonio Cultural, 18(3), 617-636.

Eurobarometer. (2016). Preferences Europeans towards tourism, n. 432. Retrieved September 20 2021, from http://ec.europa.eu/COMMFrontOffice/publicopinion/index.cfm/Survey/getSur veyDetail/instruments/FLASH/surveyKy/2065

Fairley, G. (2021). Feeling the impact of cultural tourism beyond the majors. ArtsHub Australia. Retrieved September 20, 2021, from https://www.artshub.com.au/2018/09/27/feeling-the-impact-of-cultural-tourismbeyond-the-majors-256541/

Henderson, J. C. (2011). Tourism Development and Politics in the Philippines. Tourismos: An International Multidisciplinary Journal of Tourism, 6(2), 159-173.

Horaira, M. A. (2018). Tourism in Kuakata: A Curbed Rareness in Global Village. American Journal of Trade and Policy, 5(2), 67-72.

Horaira, M. A. (2020). The Economic Impact of Tourism on to the Community of Kuakata. Asian Journal of Humanity, Art and Literature, 7(1), 43-58.

Howlader, M. Z. H. (2016), "Development of cultural tourism" available at: https://www.daily-sun.com/arcprint/details/159378/Development-of-culturaltourism/2016-08-16 (accessed 30 July 2021).

Husain, S. S. (n.d.). The arts of Bangladesh. Encyclopædia Britannica. Retrieved September 20 2021, from https://www.britannica.com/place/Bangladesh/The-arts

International Mother Language Day. UNESCO. (2021). Retrieved July 30 2021, from https://en.unesco.org/commemorations/motherlanguageday.

Ismail, N., Masron, T., \& Ahmad, A. (2014), "Cultural Heritage Tourism in Malaysia: Issues and challenges", available at: https:/www.shsconferences.org/articles/shsconf/abs/2014/09/shsconf_4ictr2014_01059/shsconf_4ict r2014_01059.html (accessed 17 September 2021).

Khawnnapa S., R. L. (2021). The Study of Cultural Tourism Development Framework for Sustainable Tourism: Case Study Lampang Province. Psychology and Education Journal, 58(1), 3844-3853.

Kiprop, J. (2018). The Culture And Customs Of Bangladesh. Retrieved July 30 2021, from https://www.worldatlas.com/articles/important-aspects-of-the-culture-ofbangladesh.html.

Latif, W. B., Islam, M. A., Mohamad, M., Kongsompong, K., \& Rahman, A. (2016). Conceptual framework of brand image for tourism industry: Tourism management and advertisement as moderators. Journal of Tourism Management Research, 3(1), $1-9$.

Lenzerini, F. (2011). Intangible Cultural Heritage: The Living Culture of Peoples. European Journal of International Law, 22(1), 101-120.

Leuschen, L., Eitzenberger, F. J., \& Thimm, T. (2020). Creative Industry and Cultural Tourism Destination Lake Constance - a media discourse analysis. Via Tourism Review, (17).

Maxwell, J. (2008). "Designing a Qualitative Study", Bickman, L. \& Debra J. R., The SAGE Handbook of Applied Social Research Methods, SAGE, pp. 214-253. 
Mcintosh, R. W., \& Goeldner, C. R. (1986). Tourism: Principles, practices, philosophies. Wiley.

Noireet, F. (2019). Sonargaon, the birthplace of Jamdani. Retrieved July 16 2021, from https://jamdanifestival.com/sonargaon-the-birthplace-of-jamdani/.

OECD (2008). The Impact of Culture on Tourism, OECD Publishing, Paris.

OECD. (2020). OECD Tourism Trends and Policies 2020: En. Retrieved August 19 2021, from https://www.oecd.org/cfe/tourism/oecd-tourism-trends-and-policies20767773.html.

Oxford Economics. (2016). The impact of heritage tourism for the UK economy. Retrieved September 20, 2021, from https://www.oxfordeconomics.com/recent-releases/theimpact-of-heritage-tourism-for-the-uk-economy.

Ozturk, A. B., Ozer, O., \& Çaliskan, U. (2015). The relationship between local residents' perceptions of tourism and their happiness: A case of Kusadasi, Turkey. Tourism Review, 70(3), 232-242.

Papadopoulou, G. (2020). Management models of tourism industry: The case of Greece. Open Science Journal, 5(1).

Pathfriend. (2020). Best places to visit in BANGLADESH. Retrieved August 30 2021, from https://pathfriend-bd.com/best-places-to-visit-in-bangladesh/.

Pizam, A., \& Milman, A. (1986). The social impacts of tourism. Tourism Recreation Research, 11(1), 29-33.

Pramanik, P. D., \& Ingkadijaya, R. (2018), "The impact of tourism on Village Society and its Environmental" available at: https://iopscience.iop.org/article/10.1088/17551315/145/1/012060/pdf (accessed 13 August 2021).

Rahman, M. W. (2012). Cultural Tourism and Bangladesh: An Overview. Bangladesh. BANGLADESH RESEARCH PUBLICATIONS JOURNAL, 7(1), 06-15.

Reisinger, Y., \& Turner, L. W. (2011). Cross Cultural Behaviour in Tourism: Concepts and analysis. Routledge. London

Richards, G. (2010). Increasing the attractiveness of places through cultural resources. Tourism Culture \& Communication, 10(1), 47-58.

Richards, G. (2011). Creativity and tourism: The State of the Art. Annals of Tourism Research, 38(4), 1225-1253.

Richards, G. (2014), "Tourism trends: The convergence of culture and tourism" available at:

https://www.academia.edu/9491857/Tourism_trends\%20_The_convergence_of_cult ure_and_tourism (accessed 20 September 2021).

Richards, G. (2018). Cultural tourism: A review of recent research and trends. Journal of Hospitality and Tourism Management, 36, 12-21.

Rojek, C., \& Urry, J. (1997). Touring Cultures Transformations of Travel and Theory. Routledge.

Shahzalal, M. (2016). Positive and Negative Impacts of Tourism on Culture: A Critical Review of Examples from the Contemporary Literature. Journal of Tourism, Hospitality and Sports, 20.

Št’astná, M., Vaishar, A., Brychta, J., Tuzová, K., Zloch, J., \& Stodolová, V. (2020). Cultural Tourism as a Driver of Rural Development. Case Study: Southern Moravia. Sustainability, 12(21), 9064

Terras, M. (2006). Qualitative research for the Information Professional. a Practical Handbook. second EDITION. * G. E. Gorman and peter clayton. Literary and Linguistic Computing, 22(2), 246-248. https://doi.org/10.1093/llc/fqm005 
Tian, D., Wang, Q., Law, R., \& Zhang, M. (2020). Influence of cultural identity on Tourists' Authenticity PERCEPTION, Tourist satisfaction, and Traveler Loyalty. Sustainability, 12(16), 6344.

Travel-News. (2020). 21st February - Historical Past, Importance \& Birthday party of Amor Ekushey. Retrieved July 18, 2021, from https://travelnews.net/2020/02/24/21st-february-history-significance-celebration-of-amorekushey/.

UNESCO. (1999). Tentative Lists. UNESCO World Heritage Centre. Retrieved July 24 2021, from https://whc.unesco.org/en/tentativelists/state=bd.

Weiermair, K. (2000). Tourists' perceptions towards and satisfaction with service quality in the cross-cultural service encounter: Implications for hospitality and tourism management. Managing Service Quality: An International Journal, 10(6), 397-409.

Wickramasinghe, W. M. G. M., \& Kumara, P. B. S. N. (2021), "A Study on the Impact of Culture \& Heritage Attributes on Tourist Satisfaction (with Special Reference to Anuradhapura)" available https://papers.ssrn.com/sol3/papers.cfm?abstract_id=3809051 (accessed 16 September 2021).

Williams, R., \& McGuigan, J. (2014). Raymond Williams on culture \& Society: Essential Writings. SAGE.

World Tourism Organization (2018). Tourism and Culture Synergies, UNWTO, Madrid.

UNWTO. (2019). World tourism organization. Retrieved July 28 2021, from https://www.unwto.org/world-tourism-barometer-n18-january-2020.

UNWTO. (2021). World tourism organization. Retrieved July 28 2021, from https://www.unwto.org/tourism-and-culture.

Zhao, J., \& Min Li, S. (2018). The impact of tourism development on the environment in China. Acta Scientifica Malaysia, 2(1), 1-4.

Zimmermann, K. A. (2017). What is culture? Retrieved May 8 2021, from https://www.livescience.com/21478-what-is-culture-definition-of-culture.html. 